\title{
WhatsApp as an Educational Support Tool in a Saudi University
}

\author{
Ahmad J Reeves ${ }^{1}$, Salem Alkhalaf ${ }^{2}$ \\ Computer Department, Qassim University \\ Alrass, Saudi Arabia
}

\author{
Mohamed A. Amasha ${ }^{3}$ \\ Department of Computer Teacher Preparation \\ Damietta University, Egypt
}

\begin{abstract}
WhatsApp is a widely used social media app, growing in popularity across the Middle East, and the most popular in Saudi Arabia. In this paper, we investigate the usage of WhatsApp as an educational support tool in a Saudi university. An online survey was constructed to ascertain how students and staff feel about and utilize WhatsApp as part of their daily studies. It also aimed to gather their thoughts on other platforms offered by the university such as Blackboard and email. The survey was tested and the results analyzed for frequency distributions, mean score, and standard deviation. Our results from nearly 200 student and staff members reveals that WhatsApp is heavily utilized for a variety of educational support tasks and greatly preferred over the other platforms. We propose that WhatsApp has good potential to support not only student coordination, information dissemination and simple enquiries but also to support formal teaching and out-of-class learning.
\end{abstract}

Keywords-Online learning; WhatsApp; e-learning; blackboard; communication; mobile learning

\section{INTRODUCTION}

WhatsApp is one of the most widely used social messaging platforms in the world, with over one billion people now using the service [1]. WhatsApp allows users to freely share text and audio messages (along with a range of other media), and form groups related to mutually interesting topics. In other words, WhatsApp offers a useful, lightweight communication tool on a mobile platform. WhatsApp and other messaging apps have become embedded into daily life for millions of people, with nearly half of smartphone owners in the US using WhatsApp or KIK [2]. The total number of WhatsApp users has also increased to 1.2 billion (see Fig. 1).

Compared to Facebook, WhatsApp messages remain private (as there are fewer privacy policy changes than Facebook), security is end-to-end on WhatsApp and response times on WhatsApp are quicker with instant notification of receipt and whether the message has been read. WhatsApp is also the top social media app in Saudi Arabia used by $56 \%$ of the population [4]. Given this popularity, in this paper, we focus on how WhatsApp is also being used as an educational support tool in a Saudi University. We want to compare how students are using WhatsApp in comparison to an existing mobile Learning Management System (LMS) and e-mail. Anecdotal evidence suggested that students used the LMS and e-mail very rarely and were more inclined to rely on social media platforms as support tools during their studies. We wished to find the extent of this usage and any potential for other educational uses.
In section two, we present a literature review of how WhatsApp has been used in educational settings and the effects (both positive and negative) on that education. In section three, we present the methodology for the study. In section four, we present the results and in sections five and six the discussion and conclusions.

\section{LiteratURE REVIEW}

Studies have shown that the use of WhatsApp in educational settings have produced either a positive effect, a negative effect or a mixture of both, either on the standard of education or the students themselves.

\section{A. Positive Effects}

Amry [5] compared teaching using WhatsApp for a unit at university with face-to-face instruction for 15 students. Results indicated the WhatsApp group had a more positive achievement for the unit undertaken and more positive attitudes to WhatsApp, specifically noting its ability to make learning easy, improved problem solving and knowledge sharing. Patil, Depthi \& Tadasad [6] in their study of WhatsApp use amongst 94 postgraduate university students found that approximately half of them used the platform to share academic information alongside their regular communications.

WhatsApp has also been found to have a positive effect when used in a blended mobile lecture environment. Barhoumi [7] reported several benefits of student usage of WhatsApp including increased discussion, collaboration and document sharing. Minhas, Ahmed \& Ullah [8] also found a positive effect of WhatsApp. In their survey of 84 university students, approximately one fifth used it for educational purposes alongside regular friends and family communication.

The previous studies focused on the student's view of WhatsApp. Gachago, Strydom, Hanekom, Simons \& Applters [9] studied three lecturer's perceptions of using WhatsApp for distance learners and an on-campus course. They found that WhatsApp helped in the facilitation and coordination of learning, with the mobility aspect 'blurring the physical and geographical boundaries'. The social nature of messaging on WhatsApp also, they noted, led to learners and facilitators engaging in more informal ways "crossing professional and social boundaries'. Although this blurring had positive outcomes, some negative aspects reported included increased stress and a lack of privacy, solved by negotiated ground rules initiated by both sides. 


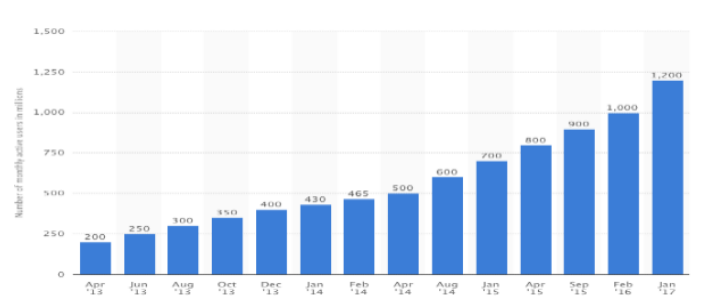

Fig. 1. Monthly Active WhatsApp users Worldwide from 2013 to 2017 [3].

\section{B. Negative Effects}

Yeboah \& Ewur [10] investigated the effect of WhatsApp on the performance of students in schools in Ghana. Fifty students were interviewed and five hundred questionnaires were taken. Apart from ease of communications and productive sharing of information, they found many undesirable effects of using WhatsApp including disruption from studies and incomplete assignments, poorer spelling and grammar and poor focus in lectures. Alosaimi, Alyahya, Alshahwan, Mahyijari \& Shaik [11] found other negative effects relating to the health of students using smartphones. They found that more than a quarter of the 2367 students they surveyed used their mobiles for more than 8 hours per day, leading to less sleeping time, decreased energy, an unhealthier lifestyle and over a quarter reported a negative effect on their academic achievement.

\section{Both Positive and Negative Effects}

Ahad \& Lim [12] in their study of WhatsApp use of 158 undergraduates found the benefits of WhatsApp included sharing academic or study related information alongside regular communications with family and friends. Negative aspects they reported included addictive like behavior in checking messages (having a negative impact on their studies) and the spread of false or unregulated information.

Bouhnik and Deshen [13] interviewed twelve instructors who had utilised WhatsApp to connect with groups they taught in high school. They reported that the WhatsApp groups are used for:

- communicating with students;

- encouraging the social atmosphere;

- building dialogue and boosting sharing among students;

- as a learning platform.

Their students highlighted both technical advantages of WhatsApp (simplicity, low cost and accessibility) and educational advantages (pleasant learning environment, the availability of learning materials, teacher accessibility, and the furtherance of learning beyond class hours). On the negative side, they also reported that instructors found the high volume of irrelevant messages annoying, differences of languages between students and privacy problematic as it was assumed teachers should be available 24 hours a day.

\section{WhatsApp in Saudi Arabia}

As this study takes place in Saudi Arabia (KSA), it is important to contextualize how WhatsApp is used in KSA in order to compare with the previous literature. Abdulkareem
[14] in a study of Saudi middle school science teachers and students found that all teachers had mobile phones and all used WhatsApp as the main social media tool. $75 \%$ of their students owned a mobile phone and $73 \%$ of students also used WhatsApp. He also found a willingness amongst both teachers and students to use WhatsApp in education, only restricted by educational infrastructure and training using this platform. In a survey of over 500 students at King Abdul-Aziz University, Aifan [15] found a positive attitude towards using social media in education with the most frequent tool used by students being WhatsApp. The only concerns raised were privacy and regulation of inappropriate content. Alqahtani [16] and Alsurehi \& Youbi [17] also found that social networking technologies might be implemented into Saudi education without major obstacles. WhatsApp was also found to have a positive affect when used to support writing skill improvement.

However, other studies have shown that even given this large usage of WhatsApp, the quality of the communication taking place can be poor. Al Lily [18] in a study of communicative content of social media messages coined the term 'information thinness' to mean the lack of information or trivial information in messages. His survey of the content of messages sent by over 700 people in KSA found that:

'Users may overuse technology merely to communicate for the sake of communication, with no interest in actually being informed by anything, thus suffering from 'information thinness'.

The previous studies have highlighted that the use of WhatsApp in educational settings have produced a variety of both positive and negative effects. In our study, we wanted to find out how WhatsApp has been used both educationally and in comparison to an existing LMS and email.

\section{Methodology}

An online survey was produced and the link distributed to both female and male students and staff in the Department of Computer Science at Qassim University in Saudi Arabia. The survey was designed to look at students' attitudes toward the use of WhatsApp in education. All participants were requested to complete the online survey via the website (https://goo.gl/forms/6o73kjHNOlsLKms43). They were provided with information about the survey and volunteered to participate after reading the importance of the study. The survey utilized a 5 -point Likert scale: $(1=$ strongly disagree, $2=$ disagree, $3=$ slightly agree, $4=$ agree, $5=$ strongly agree). It comprised 19 closed-ended questions organized in four sections: General Usage of WhatsApp (GU); Education Use of WhatsApp (EU); Other Educational Tools (OE); and Potential of WhatsApp in Education (PE). Students and staff were requested to click the Google URL to complete the survey $(\mathrm{N}=196)$. Google documents was used to collect the resultant data in spreadsheet form. The questionnaire was validated by 10 experts, and its internal reliability was found to be good. The Cronbach's $\alpha$ coefficient was found to be 0.745 .

\section{A. Data Analysis}

The resultant data was analyzed using SPSS statistical software package V.20.0. The frequency distributions, mean score, and standard deviation were computed for each item 
from the questionnaires in the Google spreadsheet. A Chisquare test was utilised to equate between actual and potential students' responses regarding the use of WhatsApp in education. The statistical significance level was fixed at $\mathrm{p}<0.05$.

\section{B. Participants}

The study at Qassim University in KSA was conducted during the first semester of the 2016-2017 academic year. Participants were selected using a systematic random method. As shown in Table I below, the number of male students was $58(29.6 \%)$ and the number of female students was 138 (70.4\%). Participants' ages ranged from 22-25 ( $M=21.92)$. In addition, the demographic questionnaire indicated that students numbered $178(90.8 \%)$ and the number of lecturers was 18 $(9.2 \%)$ (see Table I).

TABLE. I. DEMOGRAPHIC INFORMATION

\begin{tabular}{|l|l|l|}
\hline Items & Frequency $(\mathrm{n}=196)$ & $(\%)$ \\
\hline Gender & & \\
\hline Male & 58 & 29.6 \\
\hline Female & 138 & 70.4 \\
\hline Age & & \\
\hline $18-21$ & 65 & 33.2 \\
\hline $22-25$ & 80 & 40.8 \\
\hline $26-29$ & 28 & 14.3 \\
\hline $30-33$ & 7 & 3.6 \\
\hline $34+$ & 16 & 8.2 \\
\hline Are you a student or lecturer? & & \\
\hline Student & 178 & 90.8 \\
\hline Lecturer & 18 & 9.2 \\
\hline
\end{tabular}

\section{RESUlts}

\section{A. General Usage of WhatsApp (GU)}

The results in (Table II and Fig. 2) indicate that almost all participants $(\mathrm{N}=160 ; 81.6 \%)$ reported that they use WhatsApp instant messaging on their phones. There was a significant difference between participated (male, female) regarding using WhatsApp, $(\chi 2(1, \mathrm{~N}=196)=78.44, \mathrm{p}<.01)$. This highlights that the difference between the observed frequencies and the expected ones in relation to the question raised is statistically significant and not due to chance factor.

In (Table III and Fig. 3) above, summarizes the results of student's opinion about the length of time using WhatsApp identified in the analysis. These themes all relate to students' views on how long they use WhatsApp. Almost all students (82.7\%) use WhatsApp for two years $(\mathrm{M}=4.74, \mathrm{X} 2=488.13)$.

TABLE. II. USAGE OF WhATSAPP INSTANCE MESSAGING

\begin{tabular}{|c|c|c|c|c|c|c|c|c|}
\hline \multirow{2}{*}{$\mathrm{N}$} & \multirow{2}{*}{ Question } & \multicolumn{2}{|c|}{ Yes } & \multicolumn{2}{|c|}{ No } & \multirow{2}{*}{$M$} & \multirow{2}{*}{$S d$} & \multirow{2}{*}{$X^{2}$} \\
\hline & & f & $\%$ & $\mathrm{~F}$ & $\%$ & & & \\
\hline 1 & $\begin{array}{l}\text { Do you use } \\
\text { WhatsApp } \\
\text { instant } \\
\text { messaging on } \\
\text { your phone? } \\
(\mathrm{Y}) /(\mathrm{N})\end{array}$ & $\mathbb{8}$ & 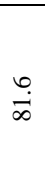 & ల & $\begin{array}{l}\stackrel{+}{\infty} \\
\stackrel{0}{*}\end{array}$ & $\stackrel{\infty}{=}$ & すo & $\begin{array}{l}\forall \\
\infty \\
\infty\end{array}$ \\
\hline
\end{tabular}

\section{Usage of WhatsApp instance messaging}

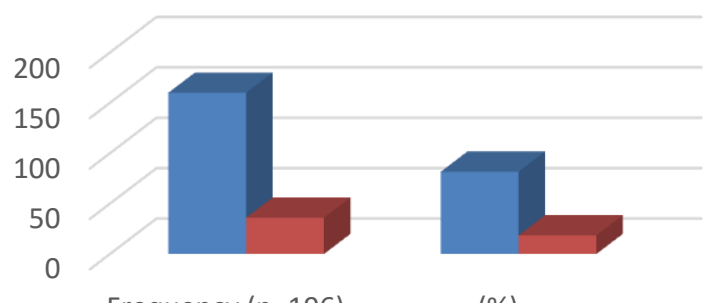

Frequency $(n=196)$

(\%)

$\square$ yes no

Fig. 2. Usage of WhatsApp Instance Messaging.

TABLE. III. LENGTH OF TIME USING WHATSAPP

\begin{tabular}{|c|c|c|c|c|c|}
\hline Items & $\begin{array}{l}\text { Frequency } \\
(\mathrm{n}=196)\end{array}$ & $(\%)$ & $M$ & $S d$ & $X^{2}$ \\
\hline $\begin{array}{l}\text { How long have yo } \\
\text { been using } \\
\text { WhatsApp? }\end{array}$ & & & \multirow{6}{*}{$\stackrel{n}{\stackrel{r}{r}}$} & \multirow{6}{*}{$\overline{0}$} & \multirow{6}{*}{$\underset{\substack{m \\
m}}{\stackrel{m}{\infty}}$} \\
\hline Less than 1 year & - & - & & & \\
\hline 1 year & 22 & 11.2 & & & \\
\hline 2 year & 162 & 82.7 & & & \\
\hline 3 year & 9 & 4.6 & & & \\
\hline More than 4 years & 3 & 1.5 & & & \\
\hline
\end{tabular}

\section{Length of time using WhatsApp}

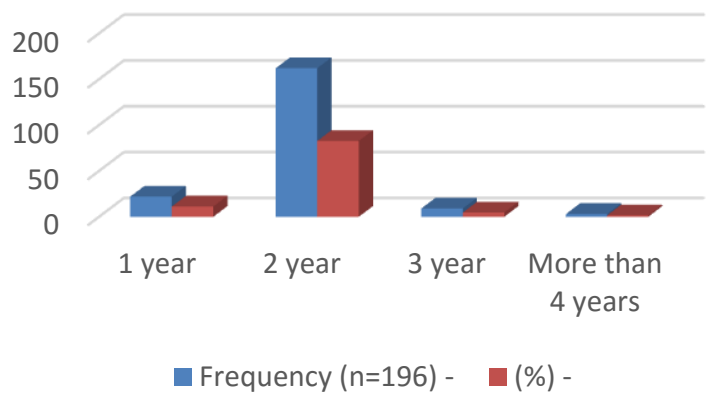

Fig. 3. Length of Time using WhatsApp.

The above question (Table IV and Fig. 4) shows that approximately half of the participants $58.7 \%$ reported that they use WhatsApp in their academic time with both lecturers and with other members of college staff $(M=2.99, \mathrm{X} 2=218.28)$. On the other hand, $21.9 \%$ used for contact with their friends. This result indicates that students are interested in using WhatsApp for an educational purpose.

In terms of content sent using WhatsApp and what students use WhatsApp with (Table V), the majority reported that they use it in all type of the content $(81.1 \%)$. The participants reported that they almost never use WhatsApp just in text messages (15.3\%). All responses are shown in Fig. 5. 
TABLE. IV. CONTACT USING WHATSAPP

\begin{tabular}{|c|c|c|c|c|c|}
\hline $\begin{array}{l}\text { Who do you contact using } \\
\text { WhatsApp? }\end{array}$ & $\begin{array}{l}\text { Frequency } \\
(n=196)\end{array}$ & $(\%)$ & $M$ & $S d$ & $X^{2}$ \\
\hline Friends & 43 & 21.9 & \multirow{5}{*}{ 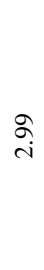 } & \multirow{5}{*}{ গิ } & \multirow{5}{*}{$\begin{array}{l}\stackrel{*}{*} \\
\underset{\sim}{\sim} \\
\stackrel{\infty}{\sim}\end{array}$} \\
\hline Family members & 34 & 17.3 & & & \\
\hline Other students & 1 & 0.5 & & & \\
\hline $\begin{array}{l}\text { Lecturers \& members of } \\
\text { college staff }\end{array}$ & 115 & 58.7 & & & \\
\hline Work colleagues & 3 & 1.5 & & & \\
\hline
\end{tabular}

\section{Contact using WhatsApp}

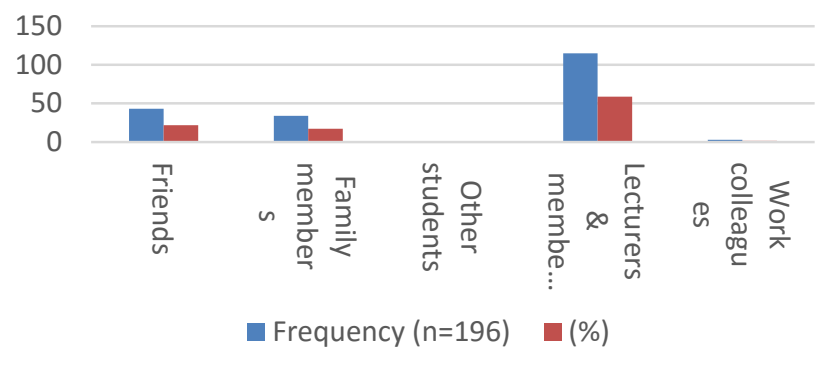

Fig. 4. Contact using WhatsApp.

TABLE. V. CONTENT SENT USING WhATSAPP

\begin{tabular}{|c|c|c|c|c|c|}
\hline $\begin{array}{l}\text { What type of content do you } \\
\text { send? }\end{array}$ & $\begin{array}{l}\text { Frequency } \\
(\mathrm{n}=196)\end{array}$ & $(\%)$ & $M$ & $S d$ & $X^{2}$ \\
\hline Text messages & 3 & 15.3 & \multirow{6}{*}{$\stackrel{m}{+}$} & \multirow{6}{*}{$\stackrel{\text { If }}{-}$} & \multirow{6}{*}{$\stackrel{\text { F }}{\underset{7}{f}}$} \\
\hline Videos & 1 & 0.5 & & & \\
\hline Audio recordings & 2 & 1.00 & & & \\
\hline Images & 4 & 2.00 & & & \\
\hline $\begin{array}{l}\text { Documents (e.g. } \\
\text { pdf/.doc/web link/maps) }\end{array}$ & 0 & 0 & & & \\
\hline All & 159 & 81.1 & & & \\
\hline
\end{tabular}

\section{Content sent using WhatsApp}

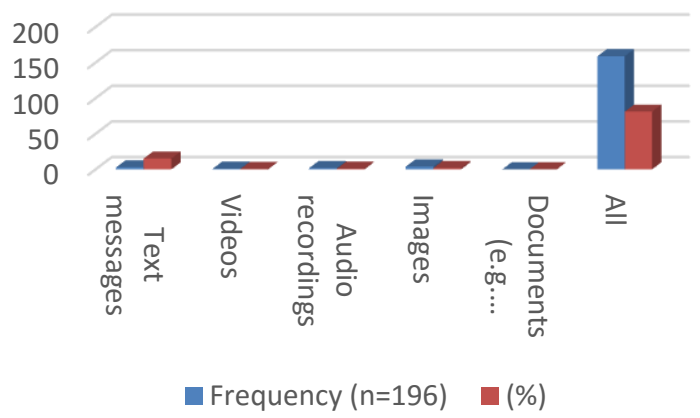

Fig. 5. Content Sent using WhatsApp.
Most students used WhatsApp for about 3-5 hours per day (see Table VI and Fig. 6). The results indicate that ( $\mathrm{M}=2.74$, $\left.\mathrm{X} 2=30.78^{* *}\right) \mathrm{X} 2$ has high statistical significance.

\section{B. Education Use of WhatsApp (EU)}

In Table VII, students reported that they used WhatsApp for text messages. We asked them about the last 7 days, how many of their WhatsApp messages do they think relate to their studies at University. Approximately half of the participants $(45.1 \%)$ reported more than 60 of their messages were related to their studies.

TABLE. VI. HOURS PER DAY USING WhATSAPP

\begin{tabular}{|c|c|c|c|c|c|}
\hline $\begin{array}{l}\text { How many hours per } \\
\text { day do you spend using } \\
\text { WhatsApp? }\end{array}$ & $\begin{array}{l}\text { Frequency } \\
(n=196)\end{array}$ & $(\%)$ & $M$ & $S d$ & $X^{2}$ \\
\hline Less than 1 hour & 34 & 17.3 & \multirow{5}{*}{$\underset{i}{\stackrel{i}{i}}$} & \multirow{5}{*}{$\stackrel{\stackrel{\Delta}{~}}{\sim}$} & \multirow{5}{*}{$\stackrel{\infty}{\stackrel{\infty}{\infty}}$} \\
\hline 1-2 hours & 55 & 28.1 & & & \\
\hline $3-5$ hours & 60 & 30.6 & & & \\
\hline 6-8 hours & 22 & 11.2 & & & \\
\hline More than 8 hours & 25 & 12.8 & & & \\
\hline
\end{tabular}

\section{Hours per day using WhatsApp}

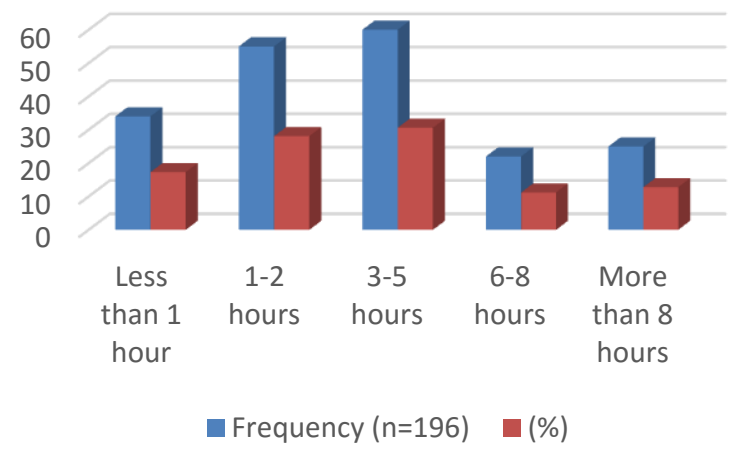

Fig. 6. Hours Per Day using WhatsApp.

TABLE. VII. NUMBER OF MESSAgES

\begin{tabular}{|c|c|c|c|c|c|}
\hline Items & $\begin{array}{l}\text { Frequency } \\
(\mathrm{n}=196)\end{array}$ & $(\%)$ & $M$ & $S d$ & $X^{2}$ \\
\hline \multicolumn{6}{|c|}{$\begin{array}{l}\text { In the last } 7 \text { days how many } \\
\text { of your WhatsApp messages } \\
\text { do you think relate to your } \\
\text { studies at University? }\end{array}$} \\
\hline None & 14 & 7.6 & \multirow{5}{*}{$\begin{array}{l}\hat{\circ} \\
\text { }\end{array}$} & \multirow{5}{*}{$\begin{array}{l}\infty \\
\dot{m}\end{array}$} & \multirow{5}{*}{$\stackrel{\text { 尊 }}{\stackrel{7}{+}}$} \\
\hline $1-20$ & 37 & 20.1 & & & \\
\hline $21-40$ & 25 & 13.6 & & & \\
\hline $41-60$ & 25 & 13.6 & & & \\
\hline More than 60 & 83 & 45.1 & & & \\
\hline
\end{tabular}


In Table VIII and Fig. 7 can be seen that the majority of students ( 74 out of $160,37.8 \%$ ) used WhatsApp in groups ( 3 or more). This result confirms the attractiveness of students to use social networks.

TABLE. VIII. WHATSAPP GROUPS

\begin{tabular}{|c|c|c|c|c|c|}
\hline $\begin{array}{l}\text { How many WhatsApp } \\
\text { groups are you a part of } \\
\text { that relate to your studies? }\end{array}$ & $\begin{array}{l}\text { Frequency } \\
(n=196)\end{array}$ & $(\%)$ & $M$ & $S d$ & $X^{2}$ \\
\hline None & 15 & 7.7 & \multirow{5}{*}{$\hat{m}$} & \multirow{5}{*}{ กิ } & \multirow{5}{*}{$\frac{10}{8}$} \\
\hline 1 & 22 & 11.2 & & & \\
\hline 2 & 27 & 13.8 & & & \\
\hline 3 & 74 & 37.8 & & & \\
\hline 4 or more & 58 & 29.6 & & & \\
\hline
\end{tabular}

\section{WhatsApp groups}

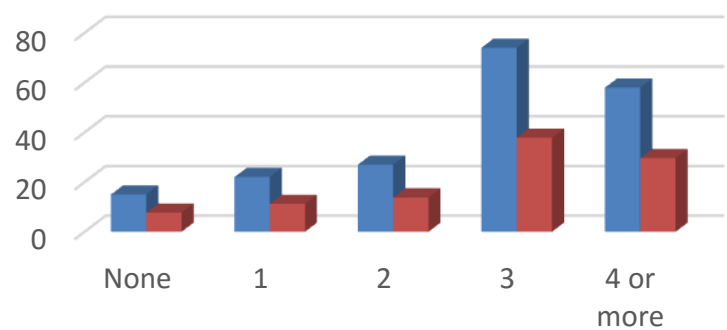

- Frequency $(\mathrm{n}=196) \quad$ (\%)

Fig. 7. WhatsApp Groups.

*p>0.01. $\quad *{ }^{*} \mathrm{p}>0.00$

Questionnaire data showed that all students used WhatsApp to exchange information regarding lecture times \& locations, questions with students, subject content, deadlines and exams and questions with a lecturer. The results in (Table IX and Fig. 8), showed high statistical significance $(\mathrm{M}=5.37$, $\mathrm{X} 2=87.12 * *)$.

According the results in (Table $X$ and Fig. 9), the students feel uncomfortable with the whole range of privacy issues whilst using WhatsApp.

TABLE. IX. TYPES OF INFORMATION SENT

\begin{tabular}{|c|c|c|c|c|}
\hline $\begin{array}{l}\text { If you use WhatsApp groups for } \\
\text { your studies, what type of } \\
\text { information is exchanged? }\end{array}$ & $\begin{array}{l}\text { Frequency } \\
(\mathrm{n}=196)\end{array}$ & $(\%)$ & $M$ & $S d$ \\
\hline Lecture times \& locations & 25 & 12.8 & \multirow{6}{*}{ ñ. } & \multirow{5}{*}{$\stackrel{q}{q}$} \\
\hline Questions with students & 6 & 3.1 & & \\
\hline Subject content & 4 & 2.0 & & \\
\hline Deadlines and exams & 1 & .5 & & \\
\hline Questions with lecturer & 0 & 0 & & \\
\hline All & 160 & 81.6 & & \\
\hline
\end{tabular}

\section{Types of information sent}

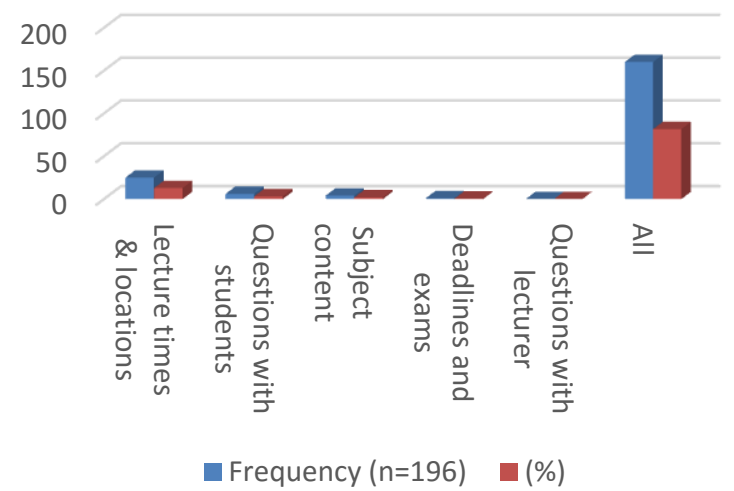

Fig. 8. Types of Information Sent.

TABLE. X. PRIVACY ISSUES

\begin{tabular}{|c|c|c|c|c|c|}
\hline $\begin{array}{l}\text { Which privacy issues do you feel } \\
\text { uncomfortable with using } \\
\text { WhatsApp? }\end{array}$ & $\begin{array}{l}\text { Frequency } \\
(\mathrm{n}=196)\end{array}$ & $(\%)$ & $M$ & $S d$ & $X^{2}$ \\
\hline Giving out your phone number & 51 & 26.0 & \multirow{6}{*}{$\stackrel{\overbrace{}}{\stackrel{n}{n}}$} & \multirow{6}{*}{ 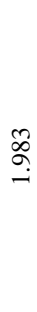 } & \multirow{6}{*}{ 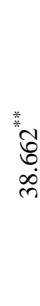 } \\
\hline Using a profile picture & 8 & 4.1 & & & \\
\hline $\begin{array}{l}\text { Discussing non-educational } \\
\text { related topics }\end{array}$ & 31 & 15.8 & & & \\
\hline Sharing personal information & 17 & 8.7 & & & \\
\hline Last seen or status information & 32 & 16.3 & & & \\
\hline All & 57 & 29.1 & & & \\
\hline
\end{tabular}

\section{Privacy issues}

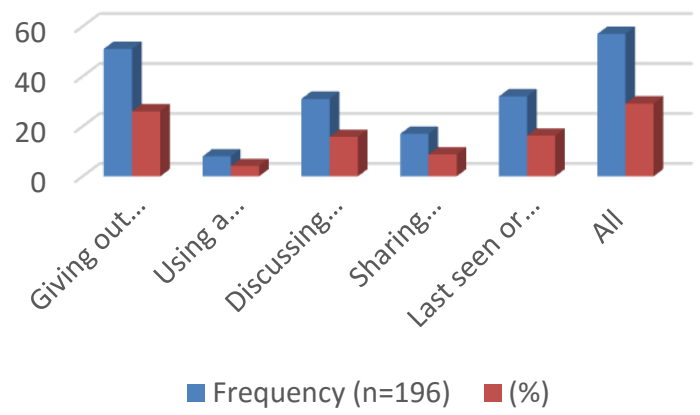

Fig. 9. Privacy Issues.

\section{Other Educational Tools (OE)}

Furthermore, the majority of our respondents (68 out of 160) never use the existing Blackboard system (see Table XI and Fig. 10). All these results are important when considering the implementation of WhatsApp in their work. Students prefer to use WhatsApp for their learning management system. This indicates that social networks are becoming a more common and friendly platform. 
TABLE. XI. USAGE OF BLACKBOARD

\begin{tabular}{|c|c|c|c|c|c|}
\hline $\begin{array}{l}\text { How often do you use the } \\
\text { existing online Blackboard } \\
\text { System? }\end{array}$ & $\begin{array}{l}\text { Frequency } \\
(\mathrm{n}=196)\end{array}$ & $(\%)$ & $M$ & $S d$ & $X^{2}$ \\
\hline Never & 68 & 34.7 & \multirow{5}{*}{$\frac{m}{\vec{i}}$} & \multirow{5}{*}{$\underset{\text { SO }}{\text { S }}$} & \multirow{5}{*}{ है } \\
\hline Once or twice per month & 56 & 28.6 & & & \\
\hline Once or twice per week & 58 & 29.6 & & & \\
\hline Every day & 7 & 3.6 & & & \\
\hline More than once per day & 7 & 3.6 & & & \\
\hline
\end{tabular}

\section{Usage of Blackboard}

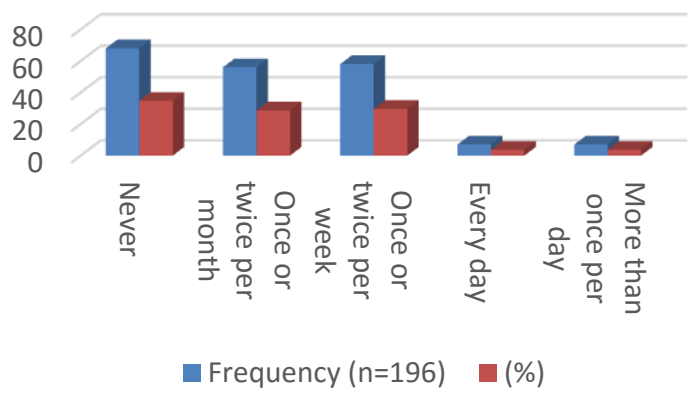

Fig. 10. Usage of Blackboard.

Furthermore, the majority of our samples (66 out of 160 , $33.7 \%$ ) never use e-mail. This result is important when considering the implementation of social media (WhatsApp) in their work. Students prefer to use social media (WhatsApp) for their learning management system. This indicates that social networks are becoming more a more common and preferred platform (see Table XII).

\section{Potential of WhatsApp in Education (PE)}

According to the results in (Table XIII), the majority of students $(n=176,90.25 \%)$ reported that WhatsApp is very easy to use.

As indicated by the parameter estimates and results in (Table XIV and Fig. 11), our respondents reported $(n=144$, $75.5 \%)$ that WhatsApp was very useful in supporting their studies and learning.

TABLE. XII. USAGE OF EMAIL

\begin{tabular}{|c|c|c|c|c|c|}
\hline $\begin{array}{l}\text { How often do you use e- } \\
\text { mail in relation to your } \\
\text { studies? }\end{array}$ & $\begin{array}{l}\text { Frequency } \\
(\mathrm{n}=196)\end{array}$ & $(\%)$ & $M$ & $S d$ & $X^{2}$ \\
\hline Never & 66 & 33.7 & \multirow{5}{*}{ 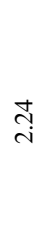 } & \multirow{5}{*}{$\stackrel{\infty}{\infty}$} & \multirow{5}{*}{ : } \\
\hline Once or twice per month & 46 & 23.5 & & & \\
\hline Once or twice per week & 54 & 27.6 & & & \\
\hline Every day & 30 & 15.3 & & & \\
\hline More than once per day & 0 & 0 & & & \\
\hline
\end{tabular}

TABLE. XIII. EASE OF USE

\begin{tabular}{|c|c|c|c|c|c|}
\hline $\begin{array}{l}\text { Overall, how easy do you } \\
\text { find WhatsApp to use? }\end{array}$ & $\begin{array}{l}\text { Frequency } \\
(\mathrm{n}=196)\end{array}$ & $(\%)$ & $M$ & $S d$ & $X^{2}$ \\
\hline Very easy to use & 176 & 90.25 & \multirow{5}{*}{$\stackrel{\vartheta}{+}$} & \multirow{5}{*}{ f } & \multirow{5}{*}{ 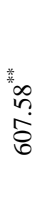 } \\
\hline Easy to use & - & - & & & \\
\hline $\begin{array}{l}\text { Neither easy or difficult to } \\
\text { use }\end{array}$ & 18 & 9.23 & & & \\
\hline Difficult to use & - & - & & & \\
\hline Very difficult to use & 1 & .512 & & & \\
\hline
\end{tabular}

TABLE. XIV. USEFULNESS OF WHATSAPP

\begin{tabular}{|c|c|c|c|c|c|}
\hline $\begin{array}{l}\text { How useful do you find } \\
\text { WhatsApp in } \\
\text { supporting your } \\
\text { studies? }\end{array}$ & $\begin{array}{l}\text { Frequency } \\
(\mathrm{n}=196)\end{array}$ & $(\%)$ & $M$ & $S d$ & $X^{2}$ \\
\hline Not useful & 3 & 1.5 & \multirow{5}{*}{$\stackrel{\infty}{+}+\underset{+}{+}$} & \multirow{5}{*}{ f } & \multirow{5}{*}{$\begin{array}{l}\stackrel{*}{*}: \\
\stackrel{+}{\forall}\end{array}$} \\
\hline Some use & - & - & & & \\
\hline Good use & 45 & 23.0 & & & \\
\hline Very useful & 148 & 75.5 & & & \\
\hline Extremely useful & -- & - & & & \\
\hline
\end{tabular}

\section{Usefulness of WhatsApp}

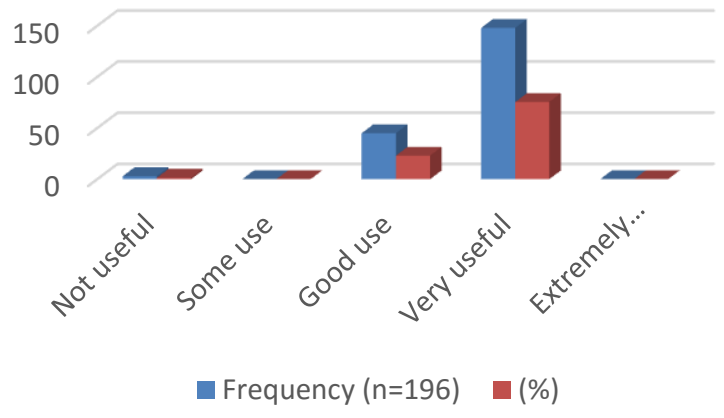

Fig. 11. Usefulness of WhatsApp.

The results shown in Table XV and Fig. 12 indicated that WhatsApp has excellent potential for teaching and learning. $37.8 \%$ of participants reported that the WhatsApp has good potential and $31.1 \%$ of participants reported that WhatsApp had excellent potential.

TABLE. XV. Potential of WhatsApP

\begin{tabular}{|c|c|c|c|c|c|}
\hline $\begin{array}{l}\text { Apart from supporting your } \\
\text { studies, how much potential } \\
\text { do you think WhatsApp has } \\
\text { for actual teaching and } \\
\text { learning? }\end{array}$ & $\begin{array}{l}\text { Frequency } \\
(n=196)\end{array}$ & $(\%)$ & $M$ & $S d$ & $X^{2}$ \\
\hline None & 13 & 6.6 & \multirow{5}{*}{$\begin{array}{c}\widetilde{c} \\
\text { r. }\end{array}$} & \multirow{5}{*}{$\stackrel{\text { a }}{\beth}$} & \multirow{5}{*}{$\begin{array}{l}\text { *o } \\
\stackrel{2}{\circ} \\
\stackrel{\infty}{2}\end{array}$} \\
\hline Minimal potential & 9 & 4.6 & & & \\
\hline Some potential & 39 & 19.9 & & & \\
\hline Good potential & 74 & 37.8 & & & \\
\hline Excellent potential & 61 & 31.1 & & & \\
\hline
\end{tabular}




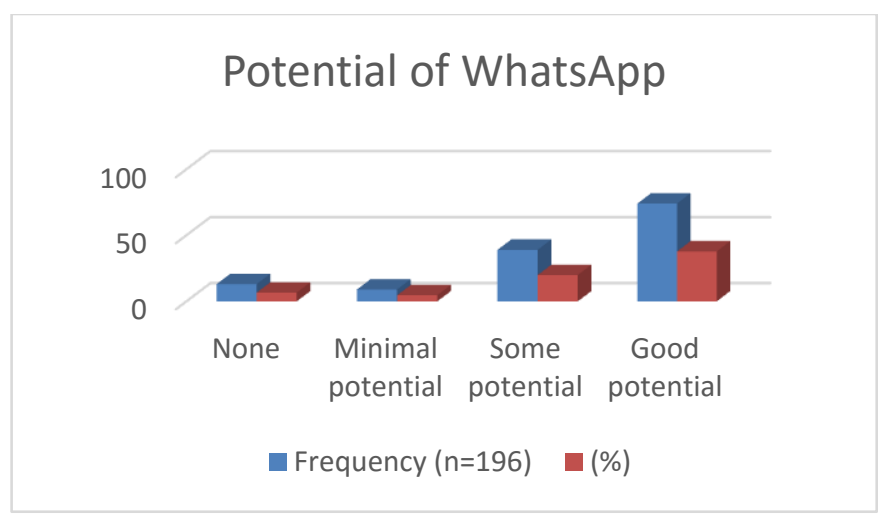

Fig. 12. Potential of WhatsApp.

WhatsApp was reported to have a positive effect on the education process by $95.4 \%$ of the students (Table XVI).

The majority of students reported that they preferred using WhatsApp to Blackboard. See Table XVII and Fig. 13.

TABLE. XVI. POSITIVE/NEGATIVE EFFECT OF WhATSAPP ON EDUCATION

\begin{tabular}{|c|c|c|c|c|c|}
\hline $\begin{array}{l}\text { Overall, do you feel WhatsApp } \\
\text { has a positive or negative } \\
\text { affect on your education? }\end{array}$ & $\begin{array}{l}\text { Frequency } \\
(\mathrm{n}=196)\end{array}$ & $(\%)$ & $M$ & $S d$ & $X^{2}$ \\
\hline Positive & 187 & 95.4 & \multirow{2}{*}{$\stackrel{\text { }}{2}$} & \multirow{2}{*}{$\stackrel{\circ}{\sim}$} & \multirow{2}{*}{$\stackrel{\text { *. }}{\stackrel{*}{\circ}}$} \\
\hline Negative & 9 & 4.6 & & & \\
\hline
\end{tabular}

TABLE. XVII. OVERALL PREFERENCE OF WHATSAPP OR BLACKBOARD

\begin{tabular}{|c|c|c|c|c|c|}
\hline $\begin{array}{l}\text { If you had to choose between } \\
\text { using either WhatsApp or } \\
\text { Blackboard to support your } \\
\text { studies, which would you choose? }\end{array}$ & $\begin{array}{l}\text { Frequency } \\
(\mathrm{n}=196)\end{array}$ & $(\%)$ & $M$ & $S d$ & $X^{2}$ \\
\hline Blackboard & 29 & 14.8 & \multirow{2}{*}{$\stackrel{\infty}{\infty}$} & \multirow{2}{*}{ 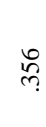 } & \multirow{2}{*}{ 草 } \\
\hline WhatsApp & 167 & 85.2 & & & \\
\hline
\end{tabular}

\section{Overall preference of WhatsApp} or Blackboard

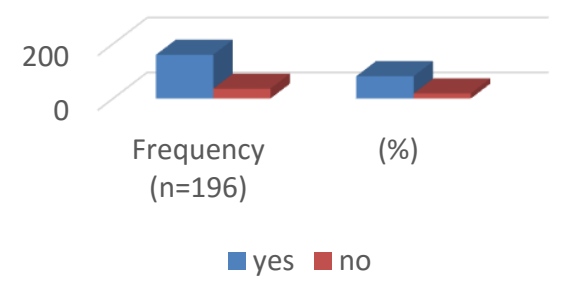

Fig. 13. Overall Preference of WhatsApp or Blackboard.

\section{DISCUSSION}

The results of our study have highlighted how widely WhatsApp has become the de-facto platform chosen by these students for both educational organization and information dissemination. With the high level of mobile phone usage in Saudi Arabia, it is evident that the educational sphere needs to understand and develop ways to exploit this phenomenon in order to support the potential that such social media channels provide. Our study has supported the previous findings that WhatsApp increases and supports both document sharing and coordination of educational information (see [9], [8] \& [15]). Our study also highlighted not only high levels of student-tostudent contact, but also student to lecturers and other members of staff. With nearly half of all messages education related, these channels (both in and out of groups) supported both students requirements for timely information but also lecturer dissemination of that information.

In comparison to the other existing platforms the university offers, WhatsApp was greatly preferred over Blackboard and email (which were hardly made use of). This may be due to the convenience of using a lightweight, always on mobile platform, over a desktop-based login system. Indeed, even though Blackboard and email are available on mobile devices, they are still not preferred methods. In could be the accessibility, usability and relative simplicity of WhatsApp makes it a first choice for students, only reverting to other existing platforms when necessary. It is also possible that students prefer to have both their social and educational messages in one platform rather than three. However, our study has reiterated how privacy issues remain an important issue with relation to WhatsApp, something future educational designers will have to consider carefully.

With regard to teaching and learning, our study has shown that WhatsApp has excellent potential to transform into not just an organizational tool but also a mainstream teaching tool. Future work will need to look at potential methods and designs that could support teaching and learning through WhatsApp beyond simple information dissemination and clarifications from members of staff. With $95 \%$ of respondents indicating that WhatsApp had a positive effect on education there is high potential for future research to see how this can be implemented.

Although our study was limited to one university, future work that assesses this trend across all universities in the Kingdom would provide a more detailed and nuanced view of both the level of social media usage and reasons for any preferences.

\section{CONCLUSIONS}

Social media platforms have been widely adopted and are continuously growing in Saudi Arabia for both social and leisure activities. This study has supported the view that WhatsApp is not only a part of this trend, but has high potential to support some of the educational needs of university students. Future work in this area need to find ways for lecturers to complement their face-to-face lectures with convenient on-line learning via WhatsApp, and also for students to maximize their learning potential from high levels of mobile screen time. 


\section{REFERENCES}

[1] Coleman, E., \& O'Connor E. The role of WhatsApp in medical education; a scoping review and instructional design model. In BMC Medical Education volume 19, Article number: 279 (2019).

[2] Alqahtani, M., Bhaskar,C., Elumalai, K.V., \& Abumelha, M. Whatsapp: An online platform for University-level English language education. Arab World English Journal (AWEJ) Volume 9, Number 4, December 2018 .

[3] Statista (2017). https://www.statista.com/statistics/260819/number-ofmonthly-active-WhatsApp-users/.

[4] Alanzi,T., Bah, S., Alzahrani, S., Alshammari, S. \& Almunsef, F. Evaluation of a mobile social networking application for improving diabetes Type 2 knowledge: an intervention study using WhatsApp. Journal of Comparative Effectiveness Research 2018.

[5] Amry, A.B. The impact of WhatsApp mobile social learning on the achievement and attitudes of female students compared with face to face learning in the classroom. European Scientific Journal August 2014 edition vol.10, No.22 ISSN: 1857 - 7881 (Print) e - ISSN 1857- 7431.

[6] Patil, S, Depthi \& Tadasad, P.G. Usage of WhatsApp messenger amongst post-graduate students in a university environment: A study of Karnataka state women's university, Vijayapura. International Journal of Multidisciplinary Research and Development Volume 2; Issue 11; November 2015; Page No. 591-594.

[7] Barhoumi, C. The Effectiveness of WhatsApp Mobile Learning Activities Guided by Activity Theory on Students' Knowledge Management. Contemporary Educational Technology, 2015, 6(3), 221238.

[8] Minhas, S., Ahmed, M \& Ullah, Q.F. Usage of WhatsApp: A Study of University Of PeshaWhatsAppr, Pakistan. International Journal of Humanities and Social Science Invention ISSN (Online): 2319 - 7722, ISSN (Print): 2319 - 7714 www.ijhssi.org |VVolume 5 Issue 7 ||July. 2016 || PP.71-73.
[9] Gachago, D., Strydom, S., Hanekom, P., Simons, S., \& WhatsApplters, S. Crossing boundaries: lecturers' perspectives on the use of WhatsApp to support teaching and learning in Higher Education. Progressio, 2015, 37(1), 172-187.

[10] Yeboah, J., \& Ewur, G.D. The impact of WhatsApp messenger usage on students performance in Tertiary Institutions in Ghana. Journal of Education and Practice, 2014, 5(6), 157-164.

[11] Alosaimi. F, Alyahya. H, Alshahwan. H, Al Mahyijari. N \& Shaik. S.A. 'Smartphone addiction among university students in Riyadh, Saudi Arabia'. Saudi Medical Journal 2016; Vol. 37 (6): 675-683 doi: 10.15537/smj.2016.6.14430.

[12] Ahad, D.A Lim, S.M.A. Convenience or Nuisance?: The 'WhatsApp' Dilemma. Procedia - Social and Behavioral Sciences 155; 2014, pp.189 $-196$.

[13] Bouhnik, D., \& Deshen, M. WhatsApp goes to school: Mobile instant messaging between teachers and students. Journal of Information Technology Education: Research, 2014, 13, 217-231.

[14] Abdulkareem, S.A. Exploring the Use and the Impacts of Social Media on Teaching and Learning Science in Saudi. Procedia - Social and Behavioral Sciences 182 (2015) 213 - 224.

[15] Aifan, H.A. 'Saudi students' attitudes toward using using social media to support learning'. PhD thesis, King Abdul Aziz University, Jeddah, KSA, 2015.

[16] Alqahtani, S. 'Effects of Social Networking on higher education on Saudi Arabia', in Issa, Isaias, Kommers (eds), Social Networking and Education, Springer, Lecture Notes in Social Networks, 2016, pp.291304.

[17] Alsurehi, H., \& Youbi, A. Towards applying social networking in higher education. International Journal of Academic Research, 2014, 6 (5), 221-229.

[18] Al Lily, A.E. Information Thinness: Saudi Arabia, The Information Society, 2015, 31:5, 407-413, DOI: 10.1080/01972243.2015.1069771. 